v. $14, n .1$

Vitória-ES, Jan.-Feb. 2017

p. $59-86 \quad$ ISSN 1808-2386

DOI: $h t t p: / / d x . d o i . o r g / 10.15728 /$ bbr.2017.14.1.4

\title{
Strategic Antecedents and Consequents for the Performance of $E$-Business Companies
}

\author{
EInivan Moreira de Souza ${ }^{\dagger}$ \\ Christus Universitary Center - Unichristus \\ Paulo César de Sousa Batista ${ }^{\Omega}$ \\ State University of Ceará - UECE
}

\begin{abstract}
This article aims to examine the influence of the strategic background and of the business model elements on its value proposition, and to investigate the relationship between the value proposition and the performance of e-business. The research is supported theoretically by the Technological, Organizational and Environmental framework (TOE), derived from the Diffusion of Innovation Theory (DIT), for the Strategic Background (IFINEDO, 2011), by the Business Model theory (OSTERWALDER; PIGNEUR; 2010; SOUZA; BATISTA, 2014) and by the business performance literature (RAMANUJAN; VENKATRAMAN, 1987). We tested the proposed model with a sample of 252 observations, using the structural equation modeling. The main results indicate a partial influence of the strategic background in the value proposition through the constructs management positioning, organizational readiness, relative advantage and pressure from stakeholders. Relating to the business model, the constructs of market segmentation, customer relationships, capabilities, partnerships and revenue model influence the value proposition, which in turn affects positively the performance of e-business companies.
\end{abstract}

Keywords: Strategic antecedents. Business models. Performance. E-business.

Received on 01/08/2015; Reviewed on 04/13/2015;Accepted on 03/23/2016; Divulgued on 01/02/2017.

*Author for correspondence:

†. Master in Administration and $\mathrm{PhD}$ Student in Administration by the University of Fortaleza - UNIFOR.

Link: Professor of the Administration Course at Christus University Center.

Address: Avenue Dom Luís, 911 - Aldeota - Fortaleza - CE -

Brazil. Cep: 60160-230.

E-mail: elnivan@hotmail.com
$\Omega \mathrm{PhD}$ in Economy by the University of Illinois. Link: Adjunct Professor of the Post-Graduate Program in Administration of the State University of Ceará. Address: Avenue Dr. Silas Munguba, 1700 - Campus Itaperi Fortaleza - CE - Brazil. Cep: 60714-903. E-mail: batista.pcs@gmail.com 


\section{INTRODUCTION}

echnological development is changing the way companies do business. One of the main sources of these transformations is the Internet, which became of great importance for doing business (e-business) and to improve the productivity of economic activities in general.

Indeed, the use of the Internet in management processes gave origin to ebusiness, which favors the integration of communication technologies with business process and management practices (KOO et al., 2007; KALAKOTA; ROBINSON, 2005).

The Internet evolved from the condition of being an information and dissemination tool and of affordable online exchanges to become the actual business model of companies, characterized by global interaction of organizational activities.

Zhu, Kramer and $\mathrm{Xu}$ (2006) stressed that the economic impact of e-businesses are universal knowledge and its potential to transform business models, organizational structures, processes and relationships with customers and suppliers.

For all these aspects, there has been growing interest in the study of various dimensions of e-business. By analyzing the literature, we were able to identify two main focal points on ebusiness studies. The first focal point comprises the analyzes of e-business Strategic Antecedents, in the form of Organizational, Technological and Environmental (TOE) Contexts, in addition to the impact of these elements on corporate performance (IFINEDO, 2011; MARTINEZ-LÓPEZ; MARTINEZ-LÓPEZ, 2010; WEISBERG; TE’ENI; ARMAN, 2011). Specifically regarding the investigation of Strategic Antecedents (TOE), the contributions by Ifinedo (2011) and Bordonaba-Juste, Lucia-Palacios and Polo-Redondo (2012), who used well established scales on this construct, are of great importance for this study.

The second group of studies are related to the activities that comprise the Business Model (CHASTON; MAGLES, 2002; OSTERWALDER, 2004; OSTERWALDER; PIGNEUR; TUCCI, 2005; WU; MAHJAN; BALASUBRAMANIAN, 2003). In this respect, the contributions of greater relevance to this study are those by Osterwalder, Pigneur and Tucci (2005). These authors developed an analysis tool, for the study of companies such as Dell, Amazon.com and eBay, which is based on four pillars: Product, Customer Interface, Infrastructure Management and Financial Management. 
In Brazil, Araújo and Zilber (2013) used this theoretical model in research conducted with small e-business companies. Santos, Seloti and Silva (2013) adopted the same model for research of traditional and gourmet bakeries. These contributions are relevant, but they did not contemplate the development of a scale to analyze the relationships of the model constructs.

With these information at hand, the authors of these research adopted as objectives: (i) to examine the influence of strategic antecedents and the constituent elements of the business model in its value proposition, and (ii) to investigate the relation between the value proposition and the corporate performance of e-businesses.

In pursuing the objectives, the research strategy we adopted was an applied survey to a non-probabilistic sample of 252 cases, of a universe comprised of managers, entrepreneurs and practitioners engaged in activities that use the Internet to do businesses. For the data analysis, we used descriptive statistics and multivariate data analysis, the latter comprised of exploratory and confirmatory factor analyses and structural equation modeling.

The relevance of this study can be explained by the economic importance of the ebusiness segment and the contribution that the model may offer to the improvement of these companies' management and the research in this type of business. In the macroeconomic dimension, the expansion of business conducted in online environment is highlighted, whose revenues grew from 0.5 billion (BRL) in 2001 to 28 billion in 2013 - an average increase of $430 \%$ per year and $5,600 \%$ accumulated over 13 years. There was an even greater adhesion of consumers via web transactions, with more than 51 million consumers purchasing, at least once in 2013, (growth of $21 \%$ over the previous year) with spending average of $350 \mathrm{BRL}$ (ECOMMERCE.ORG, 2014).

In terms of management, the study provides resource to improve the understanding of the strategic background, the business model and the impact that both have on e-businesses' performance, in addition to presenting indicators that allow measuring the allocation of resources and guide strategic decisions, according to the influence of each construct on the company's performance.

As for the academic contribution, the study seeks to help fill the gaps observed in empirical studies on the following aspects: (i) integrated treatment of strategic antecedents, business model and performance; (ii) empirical application to statistically validate or reject the model proposed by Osterwalder; and (iii) indicators that measure the impact of 
environmental variables (antecedents) and of each activity of the business model on the performance of e-business companies.

In addition to this introduction, this study is composed of three more sections and final considerations. In section 1, we present the theoretical support, the conceptual and theoretical research hypotheses. In section 2, the methodological aspects of the research. In section 3, we analyze and expose the results of the investigation. The article is closes with the final considerations of the research, indicating its limitations, the relevance of the results and suggestions for future research.

\section{THEORETICAL SUPPORT, THEORETICAL-CONCEPTUAL MODEL AND HYPOTHESES}

The implementation of e-business is more than a simple adoption of Information System (IS), since it involves a deeper integration between the internal and external management process, a closer link with partner companies, suppliers and customers, as well as managerial and strategic advantages (LUCIA-PALACIOS et al., 2014). Koo et al. (2007) define e-business as a business activity via online networks, in special, via the Internet. The use of e-business can generate benefits such as cost reduction and acquisition of new skills. The decrease of costs can occur in the supply chain and in the form of distribution (CHAKRAVARTY; KUMAR; GREWAL; 2014). New skills can be acquired, such as the ability to reach and serve a group of consumers in greater geographic coverage and to react quickly to the preferences and demands of consumers (LAUDON; TRAVER, 2010).

Technological development led the Internet to evolve from being a tool of information dissemination and affordable online exchanges to become the actual business model of companies (KALAKOTA; ROBINSON, 2005). Companies change creating or adapting their business model in such a way that there is a global integration of organizational activities.

In seeking to understand the e-business phenomenon, the literature review revealed two theoretical focus of study. The former is directed to the efforts of identifying and analyzing environmental elements that influence the adoption of e-business and the corporate performance of the e-business. These studies brought to light a consolidated framework by the TOE acronym, which encompasses the Technological, Organizational and Environmental Contexts (IFINEDO, 2011; WU; MAHAJAN; BALASUBRAMANIAN, 2003; MARTINEZLÓPEZ; MARTINEZ-LÓPEZ, 2010; TEO; PIAN, 2003; WEISBERG; TE'ENI; ARMAN, 2011). 
The second group of studies is related to the understanding of the dynamic and architecture used by these businesses. The new organizational arrangements that emerged with the use of internet/e-business technology gave rise to the term Business Model, whose centrality is the Value Proposition offered to customers (CHASTON; MAGLES, 2002; DASILVA， TRKMAN， 2014;MARKIDES; SOSA， 2013; OSTERWALDER， 2004; OSTERWALDER; PIGNEUR; TUCCI, 2005).

Based on these findings, and with the objective of unifying the two theoretical lines identified in the research, the investigation was guided by the theoretical-conceptual model shown in Figure 1 and the hypotheses underlying it.

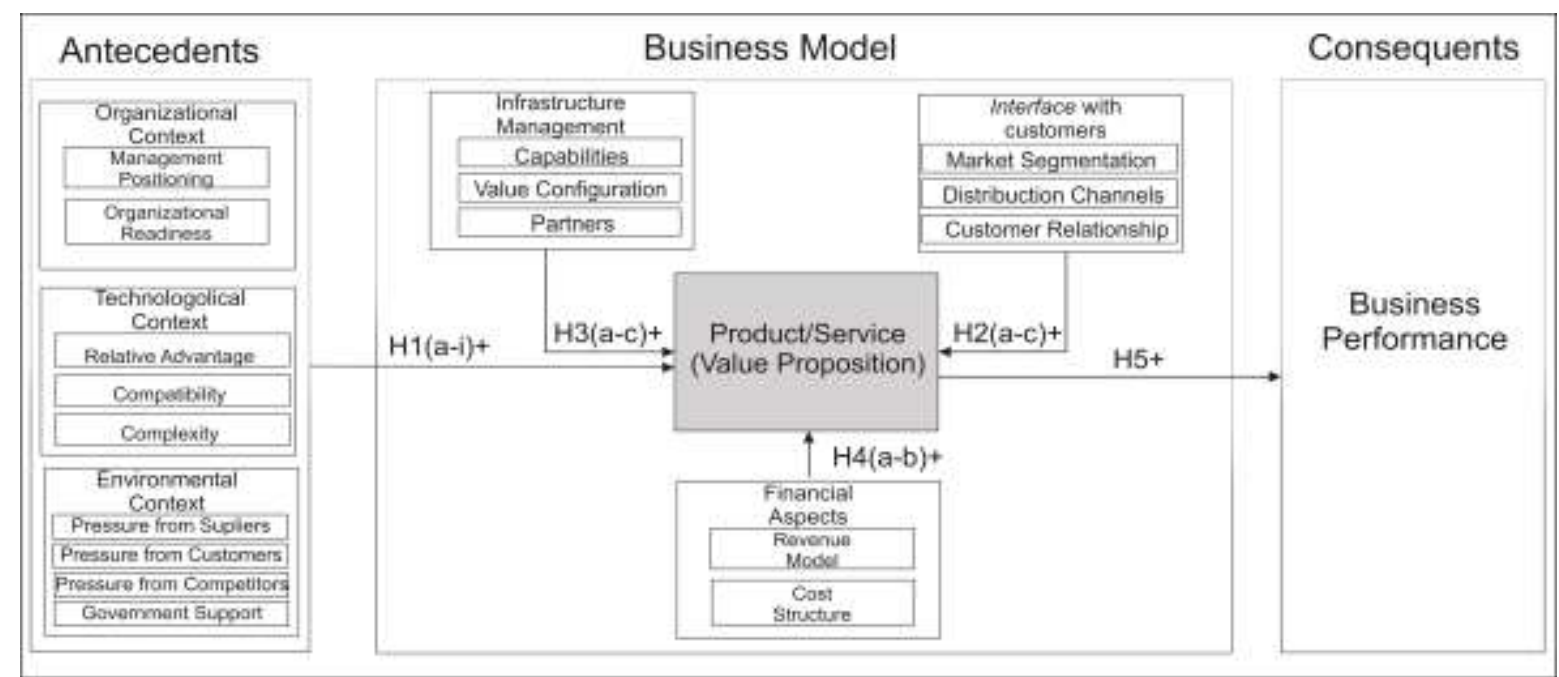

Figure 1 - Theoretical-conceptual model and research hypotheses

Source: Developed by the author based on Ifinedo (2011), Souza and Bat ista (2014) and Ramanujam and Venkatraman (1987).

\subsection{STRATEGIC ANTECEDENT ASSOCIATED WITH E-BUSINESS}

In the Organizational Context, Management Positioning and Organizational Readiness as influencing elements for the adoption of e-business. The first refers to the participation of senior management in the implementation of information systems. Jeyaraj, Rottman and Lacity (2006) found the support from the executive board to be one of the best predictors of the adoption of technology in innovations and information systems.

When senior management understands the importance of computer technology, the same tend to play a crucial role in influencing other members of the organization (IFINEDO, 2011). Conversely, when the support of management is low or nonexistent, acceptance and adoption of technologies do not take priority places in the organizational objectives.

Given these considerations, we formulate the following hypothesis:

\section{H1a - Management Positioning Positively Influences the Value Proposition.}


Organizational Readiness is defined by Iacavou, Benbasat and Dexter (1995) as the availability of resources needed for adoption of Internet/e-business technologies. These resources include not only material goods but also intangibles ones, like the human knowledge of information systems (IFINEDO, 2011, LUNARDI; DOLCI; WENDLAND, 2013). Companies with e-business experts are more likely to adopt technological innovations because they can develop their own web site or use specific technologies to improve the management of its supply chain (LIN; LEE, 2005). The absence of organizational readiness is the main harmful element to the implementation and development of e-businesses (LUNARDI; DOLCI; WENDLAND, 2013).

Based on these contributions, we formulate the following hypothesis:

\section{H1b - Organizational Readiness positively influences the Value Proposition;}

The Technological Context has its origin in the Diffusion of Innovation Theory (DIT) (ROGERS, 2003) and it is explained by the Relative Advantage, Compatibility and Complexity of Technologies constructs.

Relative Advantage is the degree to which a technology is perceived as being better than the one being currently used (ROGERS, 2003). The benefits perceived by the use of new technologies influence the adoption of e-business as well as business performance (LUCIAPALACIOS et al., 2014). Therefore, we formulate the following hypothesis:

\section{H1c - Relative Advantage positively influences the Value Proposition.}

Compatibility is defined as the degree to which an innovation is perceived as being consistent with the existing values, past experience and the needs of potential users (ROGERS, 2003). In summary, this construct expresses the evaluation of the degree of congruence between the new technology and the various aspects of the business and with the situation in which the new technology will be used. The importance of compatibility in predicting results of technology acceptance was also supported in other empirical studies (AGARWAL; PRASAD, 1997; IFINEDO; 2011). Therefore, the following hypothesis states:

\section{H1d - Compatibility positively influences the Value Proposition.}

The Complexity of Innovations is described as the degree to which a perceived innovation can be relatively difficult to understand and use (ROGERS, 2003). Consistent with DIT, the acceptance of an innovation is inhibited when it is perceived by the user as complex to be adopted. Daniel and Grimshaw (2002) proved that technologies perceived as less 
complex tend to raise greater support and acceptance among adopters than the more complex ones. Thus, the complexity is related to the perceived degree of difficulty in the process of innovation, as well as in the capacity of organizational restructuring required for its implementation (MAKAME; KANG; PARK, 2014). Therefore, we formulate the following hypothesis:

\section{H1e - Complexity positively influences the Value Proposition.}

In the Environmental Context, the pressure from Stakeholders, which include customers and suppliers Competitors and the support offered by the Government.

The introduction of stakeholders as applicants and captors of value in their interaction with the company opens an opportunity to better investigate this relationship (GARCIACASTRO; AGUILERA, 2015). The pressures from external stakeholders are also important for the adoption of e-business (CHAKRAVARTY; KUMAR; GREWAL; 2014; DEL AGUILA; PADILLA, 2008; CHONG et al., 2009). Suppliers and customers can exert great pressure, because they know that the benefits and advantages of these technologies are maximized when more people use them (LUNARDI; DOLCI; WENDLAND, 2013). Furthermore, if suppliers and customers are users of these technologies, the company will be under pressure to adapt their processes and management, in case it wishes to continue its relationship with these stakeholders (GARCIA-CASTRO; AGUILERA, 2015). Otherwise, the company will assume the risk of isolating itself in the market. Thus, the following hypotheses are formulated:

\section{H1f - Pressure from Suppliers positively influences the Value Proposition; \\ H1g - Pressure from customers positively influences the Value Proposition.}

As for the competitive pressure, there is a growing rivalry in an environment where new technologies have relevant influence and actions of competitors are unpredictable (PAVLOV; EL SAWY, 2010). In markets with high competition, obtaining updated information is seen as a basic requirement to support management decisions and technological innovation activities (CHAKRAVARTY; KUMAR; GREWAL; 2014). Thus, the following hypothesis is formulated:

\section{H1h - Pressure from competitors positively influences the Value Proposition.}

Government Support refers to the assistance provided by the government authorities to promote the use of innovative information systems in businesses. Studies examining the 
relevance of government support for the adoption of technology have produced mixed results (IFINEDO, 2011). For example, GIBBS; KRAEMER (2004) and CHAU; HUI (2001) present the existence of a significant relationship between government support and the probability of companies adopting innovations, including the use of Internet/e-business technology. Based on these studies, we formulate the following hypothesis:

\section{H1i - Government Support positively influences the Value Proposition.}

\subsection{THE BUSINESS MODEL AND E-BUSINESS}

The concept of business model does not have a clear and unequivocal definition in the literature, which has made studies on the subject difficult. More than that, this expression has been misunderstood and improperly used over the years, both by practitioners and scholars. It has often been confused with other popular terms of management literature, such as strategy, business concept, revenue model, economic model, or even business process modeling (DASILVA, TRKMAN, 2014).

The construction of the business model enables companies to deploy e-business activities, this being defined as the complex function of business processes, business applications and organizational structure required to achieve high performance. Strategies, structures and systems must be aligned for the success of virtual business (MARKIDES, 2013). Companies often have strategies that do not line up properly their structures and systems, which leads to poor performance in the implementation phase of electronic businesses (EPSTEIN, 2000). An integrated strategy should direct the investments required to develop the necessary infrastructure, not only in terms of information systems, but mainly of human resources and appropriate processes to support the virtual operation. In these circumstances, the business model concept is relevant as guidance of the company architecture for the delivery of value.

Osterwalder (2004) proposes a framework for the formulation of business models of any kind, albeit stressing that his model is more suitable for companies making intensive use of technologies because it contributes to the alignment between business, organizational and technological strategies. The Business Model proposed by this author is composed of four pillars which are divided into nine elements which constitute the scope of companies' activities.

The product/service, first pillar, is a central element in the Ontological Business Model proposed by Osterwalder, Pigneur and Tucci (2005), for it expresses the Value Proposition 
presented by the company to the market and it conditions all activities to be performed. The Value Proposition presented in the Business Model, can be understood as the statement of benefits that are delivered by the company to its customers and other stakeholders (MCNAMARA; PECK; SASSON, 2013).

The other three elements are the Market Segmentation, Distribution Channels and Customer Relationship, selected from the customer interface area. This area refers to the way the company presents itself to the market, as it actually reaches its customers and how it interacts with them (CHAKRAVARTY; KUMAR; GREWAL, 2014; OSTERWALDER, 2004; OSTERWALDER; PIGNEUR, 2010).

According to Osterwalder and Pigneur (2010), effective targeting allows a company to better allocate investment resources to target customers who will be more attracted by its Value Proposition, In addition to assisting in the decision-making process of choices of distribution channels. In view of the above, we formulate the hypotheses $\mathrm{H} 2 \mathrm{a}$ and $\mathrm{H} 4 \mathrm{~b}$, in relation to the influence of the business model elements on the Value Proposition:

\section{H2a - Market Segmentation positively influences the Value Proposition.}

The Distribution Channel corresponds to the means by which the organization can contact the customer. The activities of this construct that will interconnect Value Proposition and Market Segmentation. Its purpose is to make the right quantities of the right products or services available for the right income at the right time reach out to customers, for the right people, subject to cost, investment and flexibility constraints (MAKAME; KANG; PARK, 2014).

Thus, the following hypothesis is formulated:

\section{H2b - Distribution channels positively influence the Value Proposition.}

The activities associated with Customer Relationship define the type of connection and the strength of the relationship the company has with the client (OSTERWALDER; PIGNEUR; TUCCI, 2005). The profits of relationships with customers are the lifeblood of all businesses, and can be reached by the acquisition of new customers, increasing the profitability of existing customers and the relationships lasting length of time (CHAKRAVARTY; KUMAR; GREWAL, 2014).

Given these considerations on the relationship with the customer, we have the following hypothesis: 


\section{H2c - Customer Relationship positively influences the Value Proposition.}

The Infrastructure Management is the dimension that describes what skills are necessary to promote the Value Proposition, in line with the Customer Interface (ARAÚJO; ZILBER, 2013). In other words, it specifies the capabilities and resources of the business model, its owners and suppliers, as well as the activities that it performs and how they are related.

Wilden et al. (2013) describe the capabilities as repetitive patterns of action in the use of assets to create, produce and offer products and services to the market. Thus, a company has to have a set of capabilities, in order to provide its Value Proposition and obtain top performance. These resources depend on the goods or the company's resources (PETERAF; STEFANO; VERONA, 2013), and they increasingly outsourced to partners, using e-business technologies to maintain tight integration, which is necessary for a business to function efficiently. Having presented the main concepts and aspects of capabilities, we introduce the following hypothesis:

\section{H3a - Capabilities positively influence the Value Proposition.}

The main purpose of a business is to create value that customers are willing to pay for. This value is the result of a configuration of activities and processes inside and outside the organization (GARCIA-CASTRO; AGUILERA, 2015). The value of the configuration shows all necessary activities and the links between these, in order to create value for the customer. Thus, we have the hypothesis:

\section{H3b - Value Configuration positively influences the Value Proposition.}

Partnership is a voluntary initiative agreed between two or more organizations with the goal of creating value for customers. In the context of e-business, there are several names for these new forms of strategic networks in the process of creating value, among them the bwebs, fluid and flexible organizations and value networks (NALEBUFF; BRANDENBURGER, 1997). The appearance of such business networks significantly improved the range of possible organizational arrangements for value creation (GULATI, 1998). As a result, companies should reflect on what kind of resources the partner could leverage on their business model and on their own competencies. Therefore, we formulate the following hypothesis:

\section{H3c - Partners positively influence the Value Proposition.}


The Financial Aspects are the last block of the framework proposed by Osterwalder (2004). It is transversal because all the other pillars influence it. The Financial aspects consist of the Revenue Model and Cost Structure. Together, these factors determine the financial situation of the company and its survival ability in the competitive market. The Revenue Model measures the ability of a company to transform into cash and incoming revenue flows, the value offered to customers. It may be composed of different flows with different pricing mechanisms (DASILVA, TRKMAN, 2014; OSTERWALDER; PIGNEUR, 2010). Thus, we have the hypothesis:

\section{H4a - The Revenue Model positively influences the Value Proposition.}

The last element is the Cost Structure. This structure measures all costs generated by the company, in order to create, sell and deliver value to its customers. It sets price for all resources, goods, activities and relationships of the partners network and exchanges (OSTERWALDER, PIGNEUR, 2010). Therefore, we formulate the following hypothesis:

\section{H4b - The Cost Structure positively influences the Value Proposition.}

\subsection{BUSINESS PERFORMANCE}

Business Performance is a complex and multifaceted phenomenon, and is an issue that has received great attention in conceptual and empirical studies. For Barney (1991), the concept of business performance represents a general perception of the firm's results, resulting from a comparison of the value generated by an organization, using given capital, with the value that the owners of this capital hope to obtain.

Unlike the one-dimensional concept provided by the neoclassical economic model, the performance of companies offers a great variety. The differences between companies' performance can derive from unique resources and expertise of a specific company and from holding a privileged and protected position from the market structure. However, the performance of companies can also be explained by the relevance to a particular type of industry or economic shocks in particular years (BRITO; VASCONCELOS, 2004).

Regardless of the approach, the fact is that the information and performance evaluation are organizational tools translated to the flexibility in identifying future directions in the shortest period of time. By performance analysis, organizations can measure their survivability and continuity in view of the requirements of the internal and external environment which they are inserted in. The development of a management process which improves the translation necessarily requires the development of a systematic effort to design, 
redesign and implement systems to measure and evaluate performance (SINK; TUTTLE, 1993).

Among the many existing scales to measure performance, we opted to use the scale developed by Ramanujam and Venkatraman (1987), recently adapted by Parnel (2011) and already validated and used in Brazil by Almeida and others (2013). Given the above and the common approach to the Business Performance construct in strategy research (WILDEN et al., 2013), we have the last hypothesis and possibly the most relevant one to this research:

\section{H5 - The Value Proposition positively influences the Performance.}

\section{METHODOLOGICAL ASPECTS}

\subsection{POPULATION, SAMPLE AND RESEARCH DESIGN}

Based on the understanding that e-business consists of business activities favored by the use of the Internet (Koo et al., 2007), the world of research included managers entrepreneurs and practitioners engaged in activities using the Internet and related technologies for doing business. In this universe, we used a non-probabilistic sample of 252 cases.

As to the objectives, the research is explanatory since its main purpose is the investigation of the relationship between the strategic background, the activities of the business model and business performance. With regard to procedures, the research strategy combines bibliographical research and survey, in this case with the use of qualitative variables, the five-point Likert type. Survey respondents were selected by accessibility (MARTINS; THEÓFILO, 2009; BABBIE, 2001).

\subsection{DATA COLLECTION INSTRUMENT AND CONSTRUCTS MEASUREMENT SCALES}

For the fulfillment of the proposed objective we used, in a way that was adapted for the antecedents, the scale by Ifinedo (2011) (Table 1). For the Business Model, we used the scale by Souza and Batista (2014), which was developed based on studies by Osterwalder (2004), Osterwalder, Pigneur and Tucci (2005); and Osterwalder and Pigneur (2010) for Business Models (Table 2) and to measure business performance (Table 3) the scale developed by Ramanujam and Venkatraman (1987).

Regarding the Business Model, according to the bibliometric study by Zott, Amit and Massa (2011) on the application of the concept in empirical research and theoretical tests, we did not identify works of quantitative nature, which studies the statistical relationships of their 
theoretical constructs. This same research also indicates the model by Osterwalder and Pineur (2010) as one of the most widespread in the academic and professional field.

\begin{tabular}{|c|c|c|}
\hline \multirow{10}{*}{ 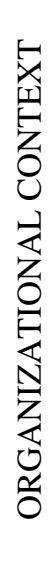 } & & MANAGEMENT POSITIONING \\
\hline & CO_PG1 & Management is interested in the use of Internet/e-business technologies on operations \\
\hline & CO_PG2 & Management supports the implementation of Interne/e-business technologies on operations \\
\hline & CO_PG3 & Management has a clear vision on the use of Internet/e-business technologies in the company \\
\hline & CO_PG4 & $\begin{array}{l}\text { Management internally discloses the need for the use of internet/e-business technologies in } \\
\text { the company }\end{array}$ \\
\hline & & ORGANIZATIONAL READINESS \\
\hline & CO_PRO1 & The company knows how information technology can be used to support its operations \\
\hline & CO_PRO2 & $\begin{array}{l}\text { The company has a good understanding of how Internet/e-business technologies can be used } \\
\text { in its businesses }\end{array}$ \\
\hline & CO_PRO3 & $\begin{array}{l}\text { The company has the technical and managerial skills needed to implement Internet/e- } \\
\text { business technologies }\end{array}$ \\
\hline & CO_PRO4 & $\begin{array}{l}\text { The company's values and standards prevents adopting Internet/e-business technologies in } \\
\text { their operations }\end{array}$ \\
\hline \multirow{13}{*}{ 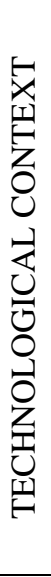 } & & RELATIVE ADVANTAGE \\
\hline & CT_VR1 & Internet/e-business technologies enable the company to manage its operations efficiently \\
\hline & CT_VR2 & Internet/e-business technologies improve the quality of the business operations \\
\hline & CT_VR3 & Internet/e-business technologies improve the efficiency of business operations \\
\hline & CT_VR4 & Internet/e-business technologies allow the company to carry out operations more rapidly \\
\hline & & COMPATIBILITY \\
\hline & CT_CB1 & $\begin{array}{l}\text { The use of Internet/e-business technologies is compatible with the company's type of } \\
\text { business }\end{array}$ \\
\hline & CT_CB2 & The use of Internet/e-business technologies fits the way the company operates \\
\hline & CT_CB3 & The use of Internet/e-business technologies fits the work style of the company \\
\hline & & COMPLEXITY \\
\hline & CT_CX1 & The use of Internet/e-business technologies requires a lot of mental effort \\
\hline & CT_CX2 & The use of Internet/e-business technologies ends up being frustrating for the company \\
\hline & CT_CX3 & The use of Internet/e-business technologies is too complex for the company's operations \\
\hline \multirow{16}{*}{ 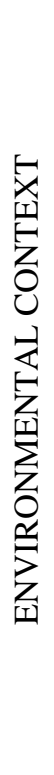 } & & PRESSURE FROM COMPETITORS \\
\hline & CA_PCP1 & The company is aware that competitors are ready to do business over the Internet \\
\hline & CA_PCP2 & The company receives pressure from competitors to adopt Internet/e-business technologies \\
\hline & CA_PCP3 & Competitors already use Internet/e-business technologies \\
\hline & & PRESSURE FROM STAKEHOLDERS \\
\hline & CA_PCL1 & The company is aware that customers are ready to do business on the internet \\
\hline & CA_PCL2 & The company receives pressure from customers to adopt Internet/e-business technologies \\
\hline & CA_PCL3 & Customers demand using Internet/e-business technologies to do business with the company \\
\hline & & PRESSURE FROM SUPPLIERS \\
\hline & CA_PFO1 & The company is aware that the suppliers are ready to do business on the internet \\
\hline & CA_PFO2 & The company receives pressure from suppliers to adopt Internet/e-business technologies \\
\hline & CA_PFO3 & Suppliers demand using Internet/e-business technologies to do business with the company \\
\hline & & GOVERNMENT SUPPORT \\
\hline & CA_SG1 & $\begin{array}{l}\text { The government provides incentives for the company to adopt Internet/e-business } \\
\text { technologies }\end{array}$ \\
\hline & CA_SG2 & $\begin{array}{l}\text { The company receives pressure from the government to adopt Internet/e-business } \\
\text { technologies }\end{array}$ \\
\hline & $\mathrm{CA}$ & $\begin{array}{l}\text { The government plays an important role for the company to adopt Internet/e-business } \\
\text { technologies }\end{array}$ \\
\hline
\end{tabular}

Table 1 - Constructs and Strategic Background Measurement Variables

Source: Adapted from Ifinedo (2011).

The scale used to measure the business model followed the taxonomy and ontological names proposed by Osterwalder (2004) (Table 2). 


\begin{tabular}{|c|c|c|}
\hline & & VALUE PROPOSITION \\
\hline \multirow{5}{*}{ 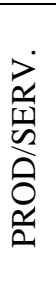 } & PS_PV1 & The product/service that the company offers perfectly meets the needs of customers \\
\hline & PS_PV2 & Products/services offered by the company are known for their quality \\
\hline & PS_PV3 & $\begin{array}{l}\text { The price of the product/service of the company has significant impact on the value } \\
\text { proposition }\end{array}$ \\
\hline & PS_PV4 & The company offers a product/service considered as innovative \\
\hline & PS_PV5 & $\begin{array}{l}\text { The life cycle of the product / service offered by the company is relatively short (less than } 1 \\
\text { year) }\end{array}$ \\
\hline \multirow{14}{*}{ 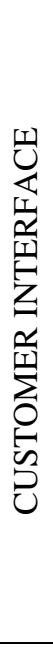 } & & MARKET SEGMENTATION \\
\hline & IC_SM1 & In the company there is a clear definition of the market segment that it serves \\
\hline & IC_SM2 & $\begin{array}{l}\text { The market segment that the company serves is directly linked to the product/service that it } \\
\text { offers }\end{array}$ \\
\hline & IC_SM3 & The company is already recognized in the market because of the product/service that is offers \\
\hline & & DISTRIBUTION CHANNELS \\
\hline & IC_CD1 & The company uses the Internet to deliver pro \\
\hline & IC_CD2 & The company uses more than one mechanism to deliver products/services \\
\hline & IC_CD3 & The company's operations are integrated with the logistics (delivery of products) \\
\hline & IC_CD4 & The type of client that the company serves is considered when choosing distribution channels \\
\hline & & CUSTOMER RELATIONSHIP \\
\hline & IC_RC1 & The company adopts a personalized relationship with customers \\
\hline & IC_RC2 & Customers put their trust in the company/brand \\
\hline & IC_RC3 & The relationship with customers is based on high switching costs (e.g. software replacement) \\
\hline & IC_RC4 & The company can retain and maintain a good relationship with customers \\
\hline \multirow{13}{*}{ 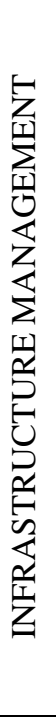 } & & CAPABILITIES \\
\hline & GI_CP1 & $\begin{array}{l}\text { The company can make good use of the resources it has to offer differentiated } \\
\text { products/services }\end{array}$ \\
\hline & GI_CP2 & $\begin{array}{l}\text { The company knows how to use machines, buildings and equipment to produce quality } \\
\text { products/services }\end{array}$ \\
\hline & GI_CP3 & $\begin{array}{l}\text { The company knows how to use the knowledge and team skills to generate innovative } \\
\text { products/services }\end{array}$ \\
\hline & & VALUE CONFIGURATION \\
\hline & GI_CV1 & es in an integrated $\mathrm{m}$ \\
\hline & GI_CV2 & The company seeks to add value by incorporating $n$ \\
\hline & GI_CV3 & Products/services offered by the company are difficult to copy \\
\hline & & PARTNERSHIPS \\
\hline & GI_PA1 & The company establishes partnerships to purchase cheaper products/services \\
\hline & GI_PA2 & The company forms partnerships to reduce environmental risks and uncertainties \\
\hline & GI_PA3 & The company forms partnerships to acquire new resources such as machines and equipment \\
\hline & GI_PA4 & $\begin{array}{l}\text { The company forms partnerships to acquire new capabilities such as patents, trademarks and } \\
\text { know-how }\end{array}$ \\
\hline \multirow{10}{*}{ 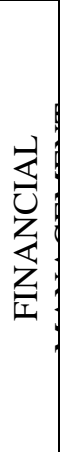 } & & REVENUE MODEL \\
\hline & GF_MR1 & The company earns revenue through the \\
\hline & GF_MR2 & The company earns re \\
\hline & GF_MR3 & The company earns revenue from advertising products/services from partner companies \\
\hline & GF_MR4 & The company earns revenue by receiving commissions \\
\hline & & COST STRUCTURE \\
\hline & GF_EC1 & The company knows the participation of each item of its cost structure \\
\hline & GF_EC2 & The company regularly monitors the cost of its activities \\
\hline & GF_EC3 & The company's costs are compatible with the costs of major competitors \\
\hline & GF_EC4 & The company's cost structure is compatible with the business model that \\
\hline
\end{tabular}

Table 2 - Constructs and Business Models Measurement Variables

Source: Souza and Batista (2014).

In order to measure the business performance, qualitative variables were used based on the satisfaction scale with the performance achieved, developed by Ramanujan and 
Venkatraman (1987) and adapted by Parnell (2011), composed of five measurement variables (Table 3).

Table 3 - Construct Performance Measurement Variables

\begin{tabular}{ll}
\hline & PERFORMANCE \\
\hline DES_1 & Sales Volume Growth \\
DES_2 & Revenue Growth \\
DES_3 & Market share \\
DES_4 & Profit Margin \\
DES_5 & Net Profit \\
\hline
\end{tabular}

Source: Ramanujan and Venkatraman (1987)

\subsection{COLLECTION PROCEDURES AND DATA DESCRIPTION}

Data were collected in November and December 2013, in events on innovation, entrepreneurship, startups, social media and digital marketing through printed and electronic questionnaires.

Respondents were asked about the strategic antecedents, formed by Organizational, Technological and Environmental contexts (IFINEDO, 2011), business models, comprised by the dimensions Product/Service, Customer Interface, Infrastructure Management and Financial Management (OSTERWALDER, 2004; OSTERALDER; PIGNEUR; TUCCI, 2005) and business performance (RAMANUJAN; VENKATRAMAN, 1987).

Table 4 - Profile of Surveyed Companies

\begin{tabular}{|c|c|c|}
\hline Profile & Frequency & Percentage (\%) \\
\hline \multicolumn{3}{|l|}{ Activity Sector } \\
\hline Trade & 68 & 27.0 \\
\hline Industry & 43 & 17.1 \\
\hline Online Service & 27 & 10.7 \\
\hline Financial Service & 20 & 7.9 \\
\hline Traditional Service & 52 & 20.6 \\
\hline Advertising & 5 & 2.0 \\
\hline Other & 34 & 13.5 \\
\hline Missing & 3 & 1.2 \\
\hline \multicolumn{3}{|l|}{ Time of the Company in the Market } \\
\hline 0 to 5 years & 80 & 31.7 \\
\hline 6 to 10 years & 40 & 15.9 \\
\hline 10 to 20 years & 41 & 16.3 \\
\hline$>20$ years & 84 & 33.3 \\
\hline Missing & 7 & 2.8 \\
\hline \multicolumn{3}{|l|}{ Annual revenue $(\mathrm{R} \$)$} \\
\hline Up to $60.000,00$ & 40 & 15.9 \\
\hline $60.000,01-360.000,00$ & 33 & 13.1 \\
\hline $360.000,01-3.600 .000,00$ & 54 & 21.4 \\
\hline $3.600 .000,01$ a $12.000 .000,00$ & 37 & 14.7 \\
\hline$>12.000 .000,00$ & 74 & 29.4 \\
\hline Missing & 14 & 5.6 \\
\hline \multicolumn{3}{|l|}{ Number of Employees } \\
\hline 0 to 19 & 89 & 35.3 \\
\hline 20 to 99 & 52 & 20.6 \\
\hline 100 to 499 & 31 & 12.3 \\
\hline$>500$ & 73 & 29.0 \\
\hline Missing & 7 & 2.8 \\
\hline
\end{tabular}


Regarding the time of companies in the market, there is a higher incidence of young companies (up to 5 years, 31.7\%) and companies in the market for longer than 20 years (33.3\%), while companies in the market between 6 and 10 years and between 10 and 20 years presented relatively close numbers (16\%) (Table 4).

\section{RESULTS PRESENTATION AND ANALYSIS}

For the treatment of data we used the software Statistical Package for the Social Sciences (SPSS), descriptive statistics modules, factor analysis and scale reliability tests and the Analysis of Moment Structures (AMOS) for the construction of the measurement and structural models.

\subsection{EXPLORATORY FACTOR ANALYSIS AND SCALE CLEANING}

The Exploratory Factor Analysis (EFA) took place through the analysis method of the main components and varimax orthogonal rotation. The criteria adopted for the EFA demanded extracted communality of the items greater than 0.4, Bartlett's sphericity test, significant at the 0.05 level, and the Keiser-Meyer-Olkin (KMO) greater than 0.50 (HAIR et al., 2009). The internal reliability analysis was used for calculating the Cronbach's alpha coefficient. As a criterion of choice, we used the classification by Hair et al. (2009).

To verify the discriminant validity, the factors of the constructs were transformed into variables and their correlations were extracted. Zero values indicate the difference between the constructs (COSTA, 2011). Once these procedures were done, it was necessary to remove six variables from the scales as they did not fit in the theoretical group (factors) nor in the statistical criteria: CO_PRO4, CA_PCL1, PS_PV5, IC_RC3, GI_CV3 e GF_MR1.

The EFA for the Environmental Context dimension constructs was done keeping the theoretical constructs initially proposed. We hoped that four factors would emerge, however, only three did. The variables from the group CA_PCL were divided into two factors. The variables CA_PCL2 and CA_PCL3 grouped together with the variables of the CA_PF group. The CA_PCL1 variable was grouped with the variables of the CA_PCP group. We verified that the variable CA_PCL1 does not have theoretical adherence in relation to the variables of the CA_PCP construct; therefore, we decided to remove this variable from the analysis. The CA_PCL2 and CA_PCL3 variables were grouped with the CA_PFO construct and, for analysis purposes, these new items were renamed as Pressure from Stakeholders (CA_PSK). This taxonomy is the same used by Del Aguila and Padilla (2008), Chong et al. (2009) and Gao, Liu and Wu (2010) and Bordonaba-Juste, Lucia-Palacios and Polo-Redondo (2012), comprising in the same construct pressure from Customers and Suppliers. The variable BBR, Braz. Bus. Rev. (Engl. ed., Online), 
CA_PCL2 was renamed as CA_PSK1, CA_PCL3 as CA_PSK2, and CA_PFO1 as CA_PSK3, CA_PFO2 as CA_PSK4, and CA_PFO3 as CA_PSK5.

The constructs of the Infrastructure Management dimension also underwent adjustments. The EFA presented only two factors instead of three. The variables GI_CV1 and GI_CV2 were grouped in the factor of the GI_CP variables. The variable GI_CV3 presented communality of 0.111 and was not grouped with any factor. By analyzing the affirmatives of the construct GI_CV, we can verify that the variables GI_CV1 and GI_CV2 are associated with capabilities more than they are with the value configuration. Thus, the GI_CV construct was dissolved. The variable GI_CV3 was excluded, the variables GI_CV1 and GI_CV2 were incorporated to the construct GI_CP being named GI_CP4 e GI_CP5, respectively.

Table 5 shows the factor structure of the constructs used in this study.

Table 5 - Factorial Structure of Constructs

\begin{tabular}{|c|c|c|c|c|c|}
\hline Dimension & KMO & $\begin{array}{l}\text { Variance } \\
\text { Explained }\end{array}$ & Construct & $\begin{array}{l}\text { Scale } \\
\text { Items }\end{array}$ & $\begin{array}{l}\text { Cronbach's } \\
\text { Alpha }\end{array}$ \\
\hline \multirow{2}{*}{ Organizational Context } & \multirow{2}{*}{0.827} & \multirow{2}{*}{$68.60 \%$} & $\begin{array}{l}\text { Management } \\
\text { Positioning }\end{array}$ & 4 & 0.839 \\
\hline & & & $\begin{array}{l}\text { Organizational } \\
\text { Readiness }\end{array}$ & 3 & 0.743 \\
\hline \multirow{3}{*}{ Technological Context } & \multirow{3}{*}{0.839} & \multirow{3}{*}{$72.60 \%$} & Relative Advantage & 5 & 0.874 \\
\hline & & & Compatibility & 3 & 0.895 \\
\hline & & & Complexity & 3 & 0.763 \\
\hline \multirow{3}{*}{ Environmental Context } & \multirow{3}{*}{0.807} & \multirow{3}{*}{$67.66 \%$} & $\begin{array}{ll}\text { Pressure } & \text { from } \\
\text { Competitors } & \end{array}$ & 3 & 0.771 \\
\hline & & & $\begin{array}{ll}\text { Pressure } & \text { from } \\
\text { Stakeholders } & \end{array}$ & 5 & 0.895 \\
\hline & & & Government Support & 3 & 0.833 \\
\hline Product/Service & 0.644 & $54.20 \%$ & Value Proposition & 4 & 0.690 \\
\hline \multirow{3}{*}{ Customer Interface } & \multirow{3}{*}{0.741} & \multirow{3}{*}{$60.65 \%$} & Market Segmentation & 3 & 0.640 \\
\hline & & & Distribution Channels & 4 & 0.736 \\
\hline & & & $\begin{array}{l}\text { Relationship } \\
\text { Customer }\end{array}$ & 3 & 0.717 \\
\hline \multirow{2}{*}{$\begin{array}{l}\text { Infrastructure } \\
\text { Management }\end{array}$} & \multirow{2}{*}{0.850} & \multirow{2}{*}{$62.58 \%$} & Capabilities & 5 & 0.831 \\
\hline & & & Partnerships & 4 & 0.821 \\
\hline \multirow{2}{*}{ Financial Management } & \multirow{2}{*}{0.713} & \multirow{2}{*}{$64.73 \%$} & Revenue Model & 3 & 0.674 \\
\hline & & & Cost Structure & 4 & 0.830 \\
\hline Performance & 0.819 & $72.36 \%$ & Performance & 5 & 0.904 \\
\hline
\end{tabular}

\subsection{A CONFIRMATORY FACTOR ANALYSIS AND MEASUREMENT MODEL}

The objectives of the CFA are to verify the factorial structure proposed and explore if any significant changes are necessary. By running the model, we verified that the aggregate values of the CFA returned some indexes below what is recommended by the literature. The $\chi$ $2 / \mathrm{df}<3$, significance level at 0.99 and RMSEA $<0.08$, however, the IFI, TLI and the CFI were below 0.90 (HAIR JUNIOR et al., 2009). 
In calculating the full model, five variables presented factor loadings below 0.50 - the PS_PV3, PS_PV4, IC_CD3, IC_CD4 and the IC_SM3 —, and all were removed. The next step was the re-specification by the covariance of the residual errors identified in the reports of the modification indexes of the AMOS $^{\mathrm{tm}}$ (BYRNE, 2010). The results indicate that the chisquare differences were statistically significant, then the re-specified models replaced the original models of the seventeen constructs. After these adjustment procedures, there was an improvement in the indicators, with the IFI, TLI and CFI (Table 6) greater than 0.90 (HAIR JUNIOR et al., 2009).

Table 6 - Statistical Adjustment Indices of the Re-Specified Model

\begin{tabular}{c|c|c|c|c|c|c|c}
\hline Chi-square $\left(\square^{2}\right)$ & Degrees of freedom $(\mathrm{df})$ & $\square^{2} / \mathrm{df}$ & $\mathrm{p}$ & IFI & TLI & CFI & RMSEA \\
\hline $2,218.921$ & 1.554 & 1.428 & 0.000 & 0.915 & 0.900 & 0.912 & 0.041 \\
\hline
\end{tabular}

Given that there were considerable changes in the constructs, we chose to again perform the procedures of convergent and discriminant validity through metrics of composite reliability (CR), average variance extracted (AVE) correlation of constructs.

Thus, by using the confirmatory factor analysis statistical technique, in order to verify the validity of the constructs and to assess whether the sets of indicators used were measuring what they should theoretically measure in terms of reliability, convergent and discriminant validity we can conclude that the results were consistent in all the constructs of the model.

\subsection{THE STRUCTURAL MODEL AND HYPOTHESIS TESTING}

The Structural Equation Modeling is a statistical method used to achieve a confirmatory framework, by means of hypothesis testing and the theory structural analysis (BYRNE, 2010). The hypothetical model can be tested statistically in simultaneous analysis of all variables to determine the consistency of the data. In terms of indicators, for the acceptance of the hypothesis, the Critical Ratio (C.R.) should be greater than 1.64 for $\mathrm{p} \leq 0.10$, greater than 1.96 for $\mathrm{p} \leq 0.05$, both for tolerable acceptance, and ideally, it should be greater than 2.58 in order to meet the adequate significance of $\mathrm{p} \leq 0.01$ (HAIR JUNIOR et al., 2009; BYRNE; 2010).

The hypotheses H1a, H1b, H1c, H1d, H1e, H1f, H1g, H1h and H1i refer to the relationship between the Strategic Antecedents (independent variables) and the Business Model (dependent variables). In Table 7, we verify that out of the eight constructs, four presented significant relationship with the Value Proposition. Therefore, hypotheses H1a, $\mathrm{H} 1 \mathrm{~b}, \mathrm{H} 1 \mathrm{c}$ and H1f-g were not rejected. Thus, we conclude that Management Positioning, Organizational Readiness, Relative Advantage and Pressure from Stakeholders positively influence the Value Proposition. 
Table 7 - Hypotheses test between Strategic Antecedents and Value Proposition

\begin{tabular}{lllllllll}
\hline $\begin{array}{l}\text { Independent } \\
\text { Variable }\end{array}$ & & $\begin{array}{l}\text { Dependent } \\
\text { Variable }\end{array}$ & Estimated & S.E. & C.R. & P & Hypothesis & Status \\
\hline CO_PG & $\rightarrow$ & PS_PV & 0.175 & 0.085 & 2.074 & $0.038^{* *}$ & H1a & A \\
CO_PRO & $\rightarrow$ & PS_PV & 0.278 & 0.092 & 3.010 & $0.003^{* * *}$ & H1b & A \\
CT_VR & $\rightarrow$ & PS_PV & 0.167 & 0.101 & 1.647 & $0.100^{*}$ & H1c & A \\
CT_CB & $\rightarrow$ & PS_PV & 0.051 & 0.081 & 0.627 & 0.531 & H1d & R \\
CT_CX & $\rightarrow$ & PS_PV & -0.095 & 0.088 & -1.077 & 0.281 & H1e & R \\
CA_PSK & $\rightarrow$ & PS_PV & 0.132 & 0.061 & 2.161 & $0.031^{* *}$ & Hf-g & A \\
CA_PCP & $\rightarrow$ & PS_PV & -0.100 & 0.096 & -1.050 & 0.294 & H1h & R \\
CA_SG & $\rightarrow$ & PS_PV & -0.082 & 0.062 & -1.331 & 0.183 & H1i & R \\
\hline
\end{tabular}

Notes: $\mathrm{p} \leq 0.10 ; * * \mathrm{p} \leq 0.05 ; * * * \mathrm{p} \leq 0.01 ; \mathrm{A}=$ Hypothesis not Rejected; $\mathrm{R}=$ Hypothesis Rejected.

In Table 8 we present the results of the hypothesis test $\mathrm{H} 2 \mathrm{a}, \mathrm{H} 2 \mathrm{~b}, \mathrm{H} 2 \mathrm{c}, \mathrm{H} 3 \mathrm{a}, \mathrm{H} 3 \mathrm{c}, \mathrm{H} 4 \mathrm{a}$ and $\mathrm{H} 4 \mathrm{~b}$, referring to the relationship between the business model constructs. According to Osterwalder and Pigneur (2010), business model elements should be directed to impact the Value Proposition. It should be highlighted that hypothesis H3b was not tested, considering that the three observable variables of the Value Configuration, in the EFA, one was excluded, and the other two were incorporated to the Capabilities construct. The hypothesis test revealed that 5 elements positively influence the Value Proposition. They are: Market Segmentation, Relationship with the Customer, Capabilities, Partnerships and Revenues Model. Only Cost Structure and Distribution Channels presented no significant relationship with the Value Proposition.

Table 8 - Hypotheses test between the Constructs of the Business Model and Value Proposition

\begin{tabular}{lllrrrrrr}
\hline $\begin{array}{l}\text { Independent } \\
\text { Variable }\end{array}$ & & $\begin{array}{l}\text { Dependent } \\
\text { Variable }\end{array}$ & Estimated & S.E. & C.R. & P & Hypothesis & Status \\
\hline IC_SM & $\rightarrow$ & PS_PV & 0.178 & 0.090 & 1.985 & $0.047^{* * *}$ & H2a & A \\
IC_CD & $\rightarrow$ & PS_PV & -0.054 & 0.047 & -1.136 & 0.256 & H2b & R \\
IC_RC & $\rightarrow$ & PS_PV & 0.588 & 0.116 & 5.061 & $0.001^{* * *}$ & H2c & A \\
GI_CP & $\rightarrow$ & PS_PV & 0.242 & 0.098 & 2.481 & $0.013^{* *}$ & H3a & A \\
GI_PA & $\rightarrow$ & PS_PV & 0.121 & 0.062 & 1.957 & $0.050^{* *}$ & H3c & A \\
GF_MR & $\rightarrow$ & PS_PV & -0.133 & 0.065 & -2.048 & $0.041^{* *}$ & H4a & A \\
GF_EC & $\rightarrow$ & PS_PV & 0.058 & 0.085 & 0.684 & 0.494 & H4b & R \\
\hline
\end{tabular}

Notes: ${ }^{*} \leq 0.10 ; * * \mathrm{p} \leq 0.05 ; * * * \mathrm{p} \leq 0.01 ; \mathrm{A}=$ Hypothesis not Rejected; $\mathrm{R}=$ Hypothesis Rejected.

In Table 9, we present H5, which is the last hypothesis tested. As all the activities of the business model should impact the Value Proposition, this one should therefore, positively influence Business Performance. It is what Table 9 shows, demonstrating statistically that the Value Proposition positively influences the Business Performance. 
Table 9 - Hypotheses Test between the Value Proposition Construct and Performance

\begin{tabular}{|c|c|c|c|c|c|c|c|c|}
\hline $\begin{array}{l}\text { Independent } \\
\text { Variable }\end{array}$ & & Dependent Variable & Estimated & S.E. & C.R. & $\mathrm{P}$ & Hypothesis & Status \\
\hline PS_PV & $\rightarrow$ & DES & 0.300 & 0.083 & 3.603 & $0.001^{* * *}$ & H5 & $\mathrm{A}$ \\
\hline
\end{tabular}

$\mathrm{p} \leq 0.01 ; \mathrm{A}=$ Hypothesis not Rejected; $\mathrm{R}=$ Hypothesis Rejected.

\subsection{DISCUSSION OF RESULTS}

We verified in the hypotheses testing that the Organizational Readiness, Pressure from Stakeholders, Management Positioning and Relative Advantage, in this order of importance directly influence the Value Proposition of e-business activities. In practice, it implies stating that the company must: (i) prepare itself internally to implement these activities; (ii) map how stakeholders (customers and suppliers) influence the purchase of its products and services; (iii) have a management that is positioned in favor of the use of Internet/e-business technology in their management processes and finally, (iv) use technologies that are safe and easy to use. The correct combination of the practice of these activities is to be able to promote a Value Proposition that is unique and difficult to copy. In the theoretical and research aspect, the results are interesting as they contribute to the prevailing notion that this field of research is in its infancy and there are still gaps to be explored, especially with regard to the understanding of non-compliance of the constructs Compatibility, Complexity, Pressure from Competitors and Government Support. The great challenge is to find out if there are other antecedents that may impact the Value Proposition.

In the Business Model, we found that the Relationship with the Customer, Capabilities, Revenue Model, Market Segmentation and Partnerships, in this order of importance, directly influence the Value Proposition. The Relationship with the Customer had the highest CR (5.061), which means that this construct is the one with the greatest impact in the Value Proposition. That is, in addition to the technological expertise necessary to create, develop and maintain e-business activities, relationship continues to be valued and the automation of business processes cannot replace it completely. The human element will continue being present and has significant impact.

Capabilities was the construct that presented the second highest CR (2.481), these are directly associated with the proper use of tangible and intangible resources present in the company, thus presenting a close relationship with the RBV (BARNEY, 1991).

In e-business activities, many businesses are characterized by the diversity of revenue sources. In addition to the traditional ones, received through the sale of goods and services, companies use Internet/e-business technologies to "monetize" their ideas. A revenue model 
itself does not define how a company creates value in its entirety, but how revenue is appropriated by the company. Having a revenue model itself does not define the business model of a company, although it is an important component of a business model (DASILVA; TRKMAN, 2014).

Market Segmentation also seems important for the formation of the Value Proposition, because it will direct the company to its target audience and will allow consumers to experience it.

Partnerships, in a coherent manner with the current context of interaction and constant sharing of information, are presented as relevant for Value Proposition. It is this rich and extensive relationship network provided by the Internet, and more specifically, through social media, the basis of partnerships of modern organizations. Knowing how to choose and maintain the right partnerships is an important element to induce and maintain Value Proposition.

Distribution channels and cost structure showed no significant relationship with the value proposition. This result deserves to be analyzed in greater depth, particularly with regard to distribution channels, because some authors consider the Internet to be a distribution channel (HONGSHUANG; LI; KANNAN, 2014).

Finally, the last hypothesis to be tested checks the influence of the Value Proposition on Business Performance, which ended up being confirmed. This result is important in that it can contribute to the acceptance of a new performance measurement logic. It is very common that managers measure their performance only analyzing financial data, i.e., the end, without properly understanding the means, that is, how the management process was performed. The results, however, suggest that to achieve a satisfactory performance companies need, first, to achieve a unique and differentiated value proposition.

\section{FINAL CONSIDERATIONS}

This study aimed to examine the influence of strategic antecedents and the elements that constitute the business model in its value proposition and only then, the relationship between the value proposition and performance of e-business companies. To this end, we identified and validated a scale for measuring the strategic antecedent and business model and elaborated a structural model to verify the relationship between the constructs of the strategic antecedent, business model and business performance. 
Albeit this study not being a new research, its results present as a contribution to the literature on e-business a validated scale for strategic antecedents. Furthermore, the theoretical-conceptual model applied allowed a methodological approach for these types of businesses, based on structural equation modeling to verify the relationship between the constructs. It presents, in this regard, the contribution in seeking to simplify strategic relationships developed in e-businesses, by using a mathematical model.

Of the eighteen hypotheses, sixteen were tested and ten were confirmed. Two hypotheses were not tested due to changes in the constructs of Strategic Antecedents and Business Models in the statistical stage. The study's initial proposal contemplates the use of seventy variables in the model, however, after the steps of scales validation and the respecification of the structural model, eleven variables were excluded, with fifty-nine (59) being kept in the final measurement model.

This first study made evident that the Value Proposition is influenced by the Strategic Antecedent, specifically Management Positioning and Organizational Readiness, comprised in the Organizational Context. Therefore, the positive attitude of upper management associated with the organizational preparation, influences the Value Proposition. Regarding the Technology Context, only Relative Advantage influences Value Proposition. It is inferred, therefore, that a technological advantage compared to other companies also impacts positively on the Value Proposition. With regard to the Environmental Context, Pressure from Stakeholders, comprised in customers and the suppliers, positively influences the Value Proposition, but this did not occur with the pressure from Competitors and Governments support, which do seem to be relevant to the Value Proposition. We concluded that, managerially, the aspects related to the context of the internal dynamics of e-business companies are more important to influence the Value Proposition than the external aspects, that do not depend exclusively on companies concrete actions.

In the analysis relating to the Business Model, out of the seven hypotheses tested, five were significant, thus partially confirming this theory. Only Distribution Channels and Cost Structure have shown not to influence the Value Proposition. Customer Relationship was the construct with the highest $\mathrm{CR}$ and the only one with significance level at 0.99 , i.e., it is the one with the most influence on the Value Proposition. The managerial implications of these results indicate that, in order of importance, Relationship with the Customer, Capabilities, Revenue Model, Market Segmentation and Partnerships influence the Value Proposition. 
The last hypothesis tested verifies whether Value Proposition influences e-businesses' Business Performance. This hypothesis was also confirmed. Therefore, managing elements of the Strategic Antecedents and Business Models that presented a significant relationship with the Value Proposition lead to a superior performance.

Although this study has contributed to theoretical and empirical levels, there are some limitations that need to be reported. The first refers to the sample, which was taken predominantly in the city of Fortaleza/CE. The use of the electronic questionnaire was intended to achieve responses from other states, however, this strategy was not effective because of subjects' resistance, resulting in less than $10 \%$ of the observations collected.

These limitations undermine the generalization of the study results, including hypothesis testing, for what we suggest expanding the research to different states in Brazil as a strategy for getting generalizable results.

The second limitation relates to the hypothesis not confirmed in the research. It is evident that the model proposed in this study must undergo reformulations, in order to increase assertiveness in understanding the operation of Internet/e-business activities.

We suggest, for future investigations, that adjustment be made to the scales in this study, aimed at strengthening its explanatory power, in addition to replicating this study in other states of Brazil, comparing between the perception of corporate professionals in states considered more and less developed, comparison between data collected in Brazil and in other developing countries and/or developed countries.

Methodologically, we suggest the use of other statistical techniques such as MANOVA, Discriminant Analysis and Logistic Regression. Thus, one can understand what led to rejection of some the hypotheses in this study. Complementarily, one can also incorporate moderating and mediating variables into the model, such as culture, activity sector, company size and time length in the market.

In terms of management, the findings of this research may guide managers to base their decisions. The managerial practice shows that the Canvas tool, conceptual basis of the business model used in this article, is used without proper knowledge of its elements and the impact it causes the Value Proposition.

Under the academic aspect, this work contributes by empirically proving that there is a relationship between some elements of Strategic Antecedents with the Value Proposition, as well as demonstrating that the theory being developed on business models are empirically BBR, Braz. Bus. Rev. (Engl. ed., Online), 
validated, and at last, the study's main contribution, which is, the Value Proposition influences the performance of e-business companies.

\section{CONTRIBUTIONS BY THE AUTHORS}

EInivan Moreira de Souza: the article and result of the research that realized as part of his dissertative work.

Paulo César de Sousa Batista contributed to the construction of the model and the development of the work, as part of the orientation of the first author in his dissertative work.

\section{REFERENCES}

ALMEIDA, F. E. B. et al. Organizational capabilities, strategic orientation, strategy formulation quality, strategy implementation and organizational performance in Brazilian textile industries. In: ENCONTRO DA ASSOCIAÇÃO NACIONAL DOS PROGRAMAS DE PÓS-GRADUAÇÃO EM ADMINISTRAÇÃO (ENANPAD), 37., 2013, Rio de Janeiro (RJ). Anais... Rio de Janeiro: ANPAD, 2013.

ARAÚJO, J. B.; ZILBER, S. N. Adoção de E-business e mudanças no modelo de negócios: inovação organizacional em pequenas empresas dos setores de comércio e serviços. Gestão \& Produção, v. 20, n. 1, p. 147-163, 2013.

BABBIE, E. Métodos de pesquisas de survey. Belo Horizonte: Ed. UFMG, 2001.

BARNEY, J. B. Firm resources and sustained competitive advantage. Journal of Management, v. 17, n. 1, p. 99-120, 1991.

BORDONABA-JUSTE, V.; LUCIA-PALACIOS, L.; POLO-REDONDO, Y. Antecedents and consequences of $e$-business adoption for European retailers. Internet Research, v. 22, n. 5, p. 532-550, 2012.

BRITO, L. A. L.; VASCONCELOS, F. C. A heterogeneidade do desempenho, suas causas e o conceito de vantagem competitiva: proposta de uma métrica. Revista de Administração Contemporânea, Ed. Especial, p. 107-129, 2004.

BYRNE, B. M. Structural equation modeling with AMOS: basic concepts, applications and programming. 2. ed. New York: Taylor \& Francis Group, 2010.

CHAKRAVARTY, A.; KUMAR, A.; GREWAL, R. Customer orientation structure for internet-based business-to-business platform firms. Journal of Marketing, v. 78, p. 1-23, sep. 2014.

CHASTON, I; MANGLES, T. E-commerce in small US manufacturing firms: a pilot study on internal competencies. Journal of Marketing Management, v. 18, p 341-360, 2002.

CHAU, P. Y. K.; HUI, H. L. Determinants of small business EDI adoption: an empirical investigation. Journal of Organizational Computer and Electronic Communication, v. 11, n. 4, p. 229-252, 2001. 
CHONG, A.Y-L. et al. Influence of interorganizational relationships on SMEs'e-business adoption. Internet Research, v. 19, n. 3, p. 313-31, 2009.

COSTA, F. J. Mensuração e desenvolvimento de escalas: aplicações em Administração. Rio de Janeiro: Editora Ciência Moderna, 2011.

DASILVA; C. M.; TRKMAN, P. Business model: what it is and what it is not. Long Range Planning, v. 47, p. 379-389, 2014.

DEL AGUILA, A.; PADILLA, A. Organizational factors affecting internet technology adoption. Internet Research, v. 16, n. 1, p. 94-110, 2008.

E-COMMERCE. Evolução da internet e do e-commerce. 2014. Disponível em: <www.ecommerce.org.br>. Acesso em: 20 dez. 2014.

EPSTEIN, M. J. Organizing your business for the internet evolution. Strategic Finance Magazine, v. 82, n. 1, p. 56-60. 2000.

GARCIA-CASTRO, R.; AGUILERA, R. V. Incremental value creation and appropriation in a world with mulitple stakeholders. Strategic Management Journal, v. 36, p. 137-147, 2015.

GAO, M.; LIU, K; WU, Z. Personalization in web computing and informatics: theories, techniques, applications and future research. Journal of International Frontiers, v. 12, n. 5, p. 607-629, 2010.

GIBBS, J. L.; KRAEMER, K. L. A cross-country investigation of the determinants of scope of e-commerce use: An institutional approach. Electronic Marketing, v. 14, n.2, p. 124-137, 2004.

GULATI, R.; SINGH, H. The Architecture of cooperation: managing coordination costs and appropriation concerns in strategic alliances. Administrative Quarterly, v. 43, n. 4, p. 781814, 1998.

HAIR JUNIOR, J. F. et al. Análise multivariada de dados. 6. ed. Porto Alegre: Bookman, 2009.

HONGSHUANG, A. L.; KANNAN, P. K. Attibuting comversions in a multichannel online marketing environment: an empirical model and a field experiment. Journal of Marketing Research, v. 51, p. 40-56, fev. 2014.

IFINEDO, P. An empirical analysis of factors influencing internet/e-business technologies adoption by SMEs in Canada. International Journal of Information Technology \& Decision Making, v. 10, n. 4, p. 731-766, 2011.

JEYARAJ, A.; ROTTMAN, J. W.; LACITY, M. C. A review of the predictors, linkages, and biases in IT innovation adoption research. Journal of Information Technology, v. 21, n. 1, p. 1-23, 2006.

KALAKOTA, R., ROBINSON, M. E-business: estratégias para alcançar o sucesso no mundo dos negócios. Porto Alegre: Bookman, 2005. 
$\mathrm{KOO}, \mathrm{C}$. et al. Do e-business strategies matter? The antecedents and relationship with firm performance. InfSyst Front, v. 9, p. 283-296, 2007.

LAUDON, K. C.; TRAVER; C. G. E-Commerce: business, technology, society. New York: Pearson Education, 2010.

LUCIA-PALACIOS, L. et al. E-business implementation and performance: analysis of mediating factors. Internet Research, v. 24, n. 2, p. 223-245, 2014.

LUNARDI, G. L; DOLCI, D. B.; WENDLAND, J. Internet móvel nas organizações: fatores da adoção e impactos sobre o desempenho. Revista de Administração Contemporênea RAC, v. 17, n. 6, p. 679-703, nov./dez. 2013.

MCNAMARA, P.; PECK, S. I. P.; SASSON, A. Competing business model, value creation and appropriation in English football. Long Range Planning, v. 46, p. 475-487, 2013.

MAKAME, W. H.; KANG, J.; PARK, S. Factors influencing electronic commerce adoption in developing countries: the case of Tanzania. South African Business Management, v. 45, n. 2, p. 83-96, 2014.

MARTINEZ-LÓPEZ, L.; MARTINEZ-LÓPEZ, F. J. Intelligent e-services and multi-agent systems for B2C e-commerce. Internet Research, v. 20, n. 3, 2010.

MARKIDES, C; SOSA, L. Pioneering and first mover advantages: the importance of business models. Long Range Planning, v. 46, p. 325-334, 2013.

MARTINS, G. A; THEÓPHILO, C. R. Metodologia da investigação científica para ciências sociais aplicadas. 2. ed. São Paulo: Atlas, 2009.

NALEBUFF, B.; BRANDENBURGER; A. Co-opetition: competitive and cooperative business strategies for the digital economy. Strategy \& Leadership, v. 25, n. 6, p. 23-28, 1997.

OSTERWALDER, A. The business model ontology: a proposition in a design science approach. 172 f. Tese (Doutorado em Gestão da Informática). Universidade de Lousanne, Suiça, 2004.

OSTERWALDER, A.; PIGNEUR, Y.; TUCCI, C. L. Clarifying business models: origins, present, and future of the concept. Communications of the Association for Information System, v. 15, may, 2005.

OSTERWALDER, A.; PIGNEUR, Y. Business model generation. New Jersey: John Wiley \& Sons Inc., 2010.

PARNEL, J. A. A. Strategic capabilities, competitive strategy, and performance among retailers in Argentina, Peru and the United States. Management Decision, v. 49, p.139-155, 2011.

PAVLOV, P.A.; EL SAWY, O.A. The 'third hand': IT-enabled competitive advantage in turbulence through improvisational capabilities. Information System Research, v. 21, n. 3, pp. 443-471, 2010. 
PETERAF, M. et al. The elephant in the room of dynamic capabilities: bringings tow diverging conversations together. Strategic Mangement Journal, v. 34, p. 1389-1410, 2013.

RAMANUJAM, V.; VENKATRAMAN, N. Planning system characteristics and planning effectiveness. Strategic Management Journal, v. 8, p. 453-68, 1987.

ROGERS, E. M. Diffusion of innovations. 5. ed. New York: The Free Press, 2003.

SANTOS, R. S.; SELOTI JR; S. L.; SILVA, R. J. R. Changing business model tradicional vs gourmet bakeries. In: IBEROAMERICAN ACADEMY CONFERENCE, 8., 2013, São Paulo. Anais... São Paulo: IAA, 2013.

SINK, D. S.; TUTTLE, T. C. Planejamento e medição para a performance. Rio de Janeiro: Qualitymark, 1993.

SOUZA, E. M.; BATISTA, P.C.S. Escala para mensuração de modelo de negócios. In: ENCONTRO DA ASSOCIAÇÃO NACIONAL DOS PROGRAMAS DE PÓSGRADUAÇÃO EM ADMINISTRAÇÃO (ENANPAD), 38., 2014, Rio de Janeiro (RJ). Anais... Rio de Janeiro: ANPAD, 2014.

TEO, T.S.H.; PIAN, Y.A contingency perspective on internet adoption and competitive advantage. European Journal of Information Systems, v. 12, n. 2, p. 78-92, 2003.

WILDEN, R. et al. Dynamic capabilities and performance: strategy, structure and environment. Long Range Planning, v. 46, p. 72-96, 2013.

WEISBERG, J.; TE'ENI, D.; ARMAN, L. Past purchase and intention to purchase in ecommerce: the mediation of social presence and trust. Internet Research, v. 21, n. 1, p. 8296, 2011.

WU, F.; MAHAJAN, V.; BALASUBRAMANIAN, S. An analysis of $e$-business adoption and its impact on business performance. Journal of the Academy of Marketing Science, v. 31, n. 4, p. 425-447, 2003.

ZHU, K.; KRAEMER, K. L.; XU, S. The process of innovation assimilation by firms in different countries: a technology diffusion perspective on $e$-business. Management Science, v. 52, n. 10, p. 1557-1576, 2006.

ZOTT, C.; AMIT, R.; MASSA, L. The business model: recent developments and future research. Journal of Management, v. 37, n. 4, p. 1019-1042, 2011. 
BBR, Braz. Bus. Rev. (Engl. ed., Online),

Vitória, v.14, n.1, Art. 4, p. 59-86, jan.-feb. 2017 